\title{
The Influence of Population Aging on Chinese Economy
}

\author{
Nan Jiang \\ No.99 Shangda Road, Baoshan District, Shanghai, China \\ 759564638@qq.com
}

Keywords: Population Aging; Supply of labor force; Social security system; Health care

\begin{abstract}
The absolute number of elderly-population in China is large and growing fast. According to the United Nations standards, China has fully entered the aging society. The aging of our country's population presents several characteristics: the aging is accelerated, the aging structure of both sexes is out of balance, and the aging of regions is out of balance. The phenomenon of accelerated aging shows that the natural population growth rate shows a downward trend, the total fertility rate is low, and the average life expectancy of the population is long. Based on the census and the population forecast of the United Nations, this paper analyzes the adverse effects of the aging of the population on the supply of labor force, capital accumulation, social security system and health care. In order to cope with the rapid population aging, we must set up a scientific population development view, and put forward some useful policy suggestions on this basis, including the saying "getting old before getting rich" is no longer in line with the current national conditions of China. The main obstacles to coping with ageing are "ageing before preparation" and "rural-urban disparity".
\end{abstract}

\section{Introduction}

In the twenty-first century, aging is a global phenomenon, and China is no exception. China was one of the first developing countries to become an aging society, just spent approximately 20 years, a very short period of time when compared to most developed countries. It is may because of the one child policy, that took into effect in 1979. China, with the world's largest population, confronted with a great challenge from its population aging. The influence of population aging is mainly on the health care, social security system, and labor market supply. For example, as a result of the aging of population, the growth rate and the absolute amount of the working age population will decline, which will lead to an inevitable labor shortage, a challenge that the China's economy will have to face. It is obvious that there is no time and chance for China to avoid this situation and keep its economy growing stably. Since population aging is an irresistible trend, the questions become clear: what kind of population aging should China take, and what kind of solution should we use in order to meet the need of sustainable development for Chinese society and economy. That are what the paper want to discuss (Table 1) [1].

Table 1 Three stages of population Aging in China

\begin{tabular}{|c|c|c|c|c|}
\hline & $\begin{array}{l}\text { Annual increase in the } \\
\text { elderly population } \\
\text { [Million] }\end{array}$ & $\begin{array}{l}\text { Average annual } \\
\text { growth rate }\end{array}$ & $\begin{array}{l}\text { Expected ageing } \\
\text { population } \\
\text { [Billion] }\end{array}$ & $\begin{array}{l}\text { Expected rate of } \\
\text { ageing }\end{array}$ \\
\hline $\begin{array}{c}\text { Stage 1 } \\
(2001-2020)\end{array}$ & 596 & $3.28 \%$ & $\begin{array}{c}2.48 \\
(2021 \text { Year })\end{array}$ & $\begin{array}{c}11.17 \% \\
\text { (2021Year) }\end{array}$ \\
\hline $\begin{array}{c}\text { Stage 2 } \\
(2021-2050)\end{array}$ & 620 & Above $3 \%$ & $\begin{array}{c}4 \\
(2050 \text { Year })\end{array}$ & $\begin{array}{l}\text { Above } 30 \% \\
\text { (2050 Year ) }\end{array}$ \\
\hline $\begin{array}{c}\text { Stage } 3 \\
(2051-2100)\end{array}$ & - - & - - & $\begin{array}{c}3-4 \\
(2100 \text { Year })\end{array}$ & $\begin{array}{l}\text { Around } 31 \% \\
(2100 \text { Year })\end{array}$ \\
\hline
\end{tabular}




\section{The Status Quo of Population Aging in China}

The Characteristics of Population Aging in China. China is the world's fastest aging process nation. The French took 115 years, the United Kingdom spent 45 years, Japan spent 25 years and with the United States for 60 years entered the aging society from adult society, but our country has just taken only nearly 18 years. In 1953, the first national census data found that the population over the year of 65 accounted for $4.41 \%$ of the total population, while this data rose to $6.96 \%$ in 2009, and the data released in 2013 showed that in 2012 this proportion had grew to $8.1 \%$ [2]. China has accomplished a population transition from "high birth rate and high mortality" to "low birth rate and low mortality rate" in a short time. So, in a word, China is a country with not only the world 's largest population, but also the largest elderly population.

The Reasons for the Aging of Chinese Population. The main reason for population aging is the decline in the birth rate and the rise in life expectancy. Because of the family planning policy of "raising population quality and controlling population size" initiated in the late 1970s, China has accomplished a population transition from "high birth rate, high moral rate and high growth rate" within a short time frame. On the one side, the total birth rate in China has decreased from 5-6 births per woman in the $1950 \mathrm{~s}-1960$ s to $2-3$ births at the end of $1970 \mathrm{~s}$, and to even lower than replacement level in the early 1990s (less than 2.1 births) [3]. And now, the number declined further to 1.5 births or less. Taking into consideration of the experiences of other East Asian economies, such as Japan, Korea, Hong Kong, and Taiwan, we can find that the trend toward declining fertility will continue and will be difficult to change. The declining fertility will lead directly to a decline in the proportion of children in the total population. On the other side, the life expectancy of the population in China is rising all the time, from nearly forty in the early 1950s to 71.4 in 2000 (69.93 for male and 73.33 for females) [3]. Since life expectancy is actually not a controllable policy variable, policies affecting the birth rate are the only variable that can influence the process of population aging. It is naturally to assume that for a huge country like China, the problem of the aging population is more serious than other countries.

\section{The Influences of Population Aging on China's Economy}

The aging population in China is not a natural evolution process. This is why China differs so significantly from other countries. That is to say, China has accomplished a process of population transition at a relatively low level of social and economic development, and ushered in a premature ear of aging. The rapid aging of the Chinese population has turned into a time bomb limiting China's economic development, including the labor market and the social security system [4].

Labor market. China is a country based on labor intensive industries, and the fastest economic development achieved in recent years is mainly relies on our abundant labor force who work for the production of cheap labor-intensive products. In such way, China gains advantage in international competition than other foreign countries. However, aging of population will reduce such advantages: on one hand, aging of population causes decline of labor supply. Economic development appeals increasing demand of labor force. According to the principle of supply and demand relationship, the decrease of labor supply will result in increase of labor remuneration and the growth of labor cost. On the other hand, demographic aging reduces labor productivity., labor intensive industries lay more emphasis on staff's endurance and adaptability. However, along with the growth of workers' age, their physical function is deteriorating, and their physical strength as well as brains are decaying. They are unable for the current job, while elderly workers can hardly fit in new technologies or new equipment operation when enterprise adopts them. It materially reduces labor productivity and causes negative effect on economic development directly.

Shortage in Labor Supply. China has a large old age population and working age population. It has not only greeted its golden population structure but also been faced with an aging population, as the effectively implemented one-child policy has caused a deep drop in fertility and a rapid decline in the proportion of the youth and a rapid increase in the proportion of the old. In 1990s, China began to enjoy a sufficient labor supply, and witness a decline in the large population, that's 
the result of productive population structure [5]. As the one child policy continues to carry forward, the growth of the working age population in China becomes slower and slower, but the population aging speeds up.

Aging of Chinese population is followed by a reduction in labor supply and a stable increase in labor demand. The paper study the influence of aging population in the labor market in both fields. From the aspect of labor supply, the Chinese academy of social sciences published "China aging development report blue book" pointed out that Chinese working-age population changes into negative historical turning point, down from 940 million in 2011 to 2012 in 939 million and 2013 in 963 million, labor force supply structure began to change. In our country, the compulsory age at retirement has been 60 years old for man, and 52.2 years old for women, with some variation in actual age at retirement. The skillful professionals and officers who are in a high rank are requested to retire later. The Chinese compulsory retirement age, compared to the other countries, are very low. The young people, nowadays, are more likely to go on with their study in the age of $20 \mathrm{~s}$, the suitable age to enter into the job market. This implies that there is a large shortage in labor market supply.

In order to making it more clearly, the paper divided the working-age population into the four age groups, 15-24, 25-39, 40-54, and 54-64 years old, and find that the proportion of the 15-24 years old and 25-39 years old age group populations will continue to decline, during the period of 2000-2030. While the proportion of the 40-54years old age group population will first decline before going down. The trend means that not only the Chinese population is aging, but also the working-age population is aging, too. In other words, labor supply is going to reduce, when the large of the15-24 age group population continues their schooling and the important part of the 55-64 age group population will retire from the labor market. The proportion of Chinese working age population will change in many ways that to those in developed countries. The decline in labor market supply, accompanied with the slowing down in capital formation and a declining required rate of return on capital makes the capital labor ratio to increase. This decline the marginal product of capital involve in the marginal product of labor. As a result, the real wage goes up.

Taking the labor demand into consideration, in an era of globalization, many goods and capital can exchange freely across the countries, but the flow of labor force is limited. However, Chinese comparative advantage lies mostly in labor resources. So, China will continue to depend on the huge labor force to support its economic growth [6]. The manufacturing industries and service have been the two important industries for employment. Because of the huge growth potential, they will continue to generate a great number of labor demand. What's more, other sector and industrial department also need a good deal of labor for their future development.

Low Labor Productivity. Demographic aging causes negative effect on the increase of labor productivity. Elderly labor force can hardly fit in high-efficiency production activities, especially labor-intensive production, counting against the increase of labor productivity. It takes more time for elderly labor force to learn new knowledge and scientific technologies than young people. And the elderly also has lower adaptability to emerging industry, causing negative effect on new goods development and technology renovation of enterprise. Considering the fast growth of science and technology, efficient knowledge advance and increasingly fierce competition, aging of labor population is more unfavorable to labor productivity increase and economic growth. However, concerning countries and regions, developed countries and regions are based on technology intensive industries, and the increase of labor productivity mainly relies on science and technology and appeals more mental ability than labor for staff. Therefore, aging of labor force population causes less negative effect on the increase of labor productivity in developed countries. Comparably, some developing countries and regions, especially China, suffer more negative effect caused by aging of the labor force population.

\section{Social Security System}

Population aging has a direct influence on the financial situation of all sorts of social security funds, including the pension and the public medical care. In the pension system, the mandatory social 
insurance scheme's benefits will not keep pace with the rising cost of living, yet the market for voluntary pensions is still underdeveloped. China's medical benefits fund is designed based on the revenue from active-employees who pay for the medical insurance and expenditure by not only active-employees but also retires who do not need to pay but are covered by medical insurance. Therefore, from theoretical point of view, the aging tendency of population will definitely caused the increase of the pension expenditure and medical care expenditure.

Pressure on the Pension System. China has already entered into aging society, which means young people are providing for more the elderly. While the stress of pension payment increases, several provinces have got problem as income cannot meet expenditure. They have no other choice than compensating it with state budget, so the elderly welfare increase expenditure and limit social extended reproduction., and cause more pressure on the pension system.

In the process of population aging and industrialization, the growth of retired people is higher than the increase of population in general. Calculated with the data indicated in the Sixth National Population Census of People's Republic of China and the "China Statistical Yearbook", Chinese elder people have been increasing by about 3\%, and retired people have been growing by about $7 \%$ every year in the recent over ten years. As Chinese pension payment is mainly implemented by Pay As You Go model, lacking sufficient historic accumulation, the fast growth of retire people cause enormous stress on pension insurance supply, and some pension funds even meet problems of not making both ends meet and pending payment, which are increasingly expanding and worsening. All in all, such beyond income situation of pension funds is just a beginning, and this situation is going worse along with the reach of peak of population aging [7].

High Expenditure on Medical Care. Nowadays, Chinese health expenditure per capita is constantly increasing, and it is causing growing stress on health system. People of different ages have significant difference in health expenditure per head. And it's visible that elder people's health expenditure per head is much higher than people of other ages. Thus, the change of demographic age structure and the increase of population aging will cause significant influence on Chinese health expenditure per capita in future. Since 2000 China's aging population percentage has been increasing year by year, and reached to $9.39 \%$ in $2012,34.9 \%$ higher than 2000 . As indicated by the statistical data of National Bureau of Statistics of the People's Republic of China and Ministry of Health, China's health expenditure per head and aging population proportion showed synchronous growing trend, as RMB 361.9 /person increased to RMB 1962.7/person in 2012, growing by 4.42 times. Compared to young people, over-65-year old people suffer body aging and have higher morbidity rate, so the old people's health expenditure per head is higher. As shown by research, elder health expenditure per head is 3 5 times of young people, and the old's annual medical fee per head is 2.56 times of the average figure. It means elder population that occupy about $10 \%$ of the total population consume about $30 \%$ of medical fee per head. According to human physical evolution, $80 \%$ of the medical fees that we spend in our lifetime incurs after the age of 60 , but majority of the old have difficulty in seeking medical attention currently in China. Meanwhile, along with the economic development of China, although the government is keeping increasing investment in health industry, the health resources distribution structure of China is still unbalanced and unfairness exists in health services for urban and rural residents due to the large income gap between urban and rural residents and substantial difference between urban and rural infrastructure, etc. [8]. According to the related data, the state and all levels of national budget concentrate $80 \%$ of their health investment in cities, while $80 \%$ of such investment is concentrated in major hospitals in cities. Therefore, high medical fee not only causes huge burden for the elderly who go to see a doctor, but also give a material challenge to the future economic development of China.

The Relationship Between Labor Market and Social Security System. Social security forms an important part in the modern labor market, since any complete labor market cannot run smoothly without a sound and matching social security system. Sound social security system can drive the healthy development of labor market. For example, every worker who enters into the labor market runs unemployment risk which means income interruption and difficulty in 
maintaining basic life in such period. Without solving such problem, workers will hesitate to enter into labor market, causing labor force shortage in the market. Thus, it's necessary to set up an associated social security system, especially the unemployment insurance system which provides workers with basic life security during their unemployment and keep them away from running out of means of support in case of unemployment, no matter what job or career they did previously. Therefore, the labor market is closely related to the social security system, while they jointly affect all facets of Chinese economic development.

\section{Summary}

Along with the progress of demographic aging, increase can be seen in elder's demands of quantity and quality of foods, garments, housing, health service, senior citizen care, education, culture, entertainment and other fields. The booming of elder population consuming market will stimulate the fast growth of industries that serve senior citizens.

Develop old-age medical health care service, and ensure that "health care service is available to all elders". The coverage of health security shall be expanded, since more people join in insurance, more insurance fund we have. In consequence, risks can be distributed in larger scope, while each individual is more resistant to risk. The current insured organizations and individuals are mainly state-owned and collective enterprises, their staff and retired people. In future, the government shall expand the basic health insurance system to all kinds of enterprises and individuals, and increase health insurance fund by promulgating law and related policies [9]. Moreover, based on our national conditions, the Chinese-style retirement housing mode shall be established on basis of family retirement service, rely on community senior welfare and social service system, and be supplemented by senior social welfare institutions [10]. Because of the restriction of economic development and ideological influence, most elder people prefer to stay at home, and over half of them live with their married son or daughter. Such family mode permits the young old to help their son or daughter with housework, and help to take care of the kids, while enjoying economic support and emotional consolation from their son or daughter. Meanwhile, their married son or daughter can resolve their problem of housing.

\section{References}

[1] Y.S. Ji, and F. Teng: A study on the impact of population Aging on Economic structure in China, Social Science Series, (2013) No.01, p.103-108. (In Chinese).

[2] Z.W. Li: The influence of population Aging on China's Economic and Social Development and Countermeasures, China international finance and economics, (2018) No.01, p.22-25. (In Chinese).

[3] C. Yuan, and L. I. Ru: The Impact of Population Aging on Life Insurance Consumption in China, Journal of Central University of Finance \& Economics, (2017) No.32, p.103-121.

[4] X.M. Gai, and S. Zhang: The impact of Aging population on China's Economic growth: from the Perspective of Labor supply and Capital Investment, Shandong social science, (2018) No.06, p.37-41. (In Chinese).

[5] J.X. Wang: Research on the Influence of Population Aging on the Consumption Disparity of Chinese Rural and Urban Residents_-Based on the Empirical Analysis of Provincial Dynamic Panel Data, Modern Economic Science, (2015) No. 5, p.16.

[6] Q.P. Lu: Study on the Influence of the Aging of Rural Population on Agricultural Economy in China, Reformation \& Strategy, (2016) No.10, p.112.

[7] L. I. Hua: The Influence of Population Aging on Service Industry Development in China, Shanghai Journal of Economics, (2015) No.01, p.65.

[8] C. Sui: The influence of the changing trend of population Aging level on Economic growth in China in the background of the "two Children in all" Policy, Journal of Hebei university of economics and trade, (2018) No.03, p.70. (In Chinese). 
[9] J. Yang, and Y. Luo: The Dynamic Analysis of China Population Aging Technological Innovation and Economic Growth, Science \& Technology \& Economy, (2015) No.05, p.82.

[10] W.L. Sun, and X. Yuan: China's New Development Strategy in the Post-demographic dividend era: from the Perspective of the Economic impact of Aging, Henan social science, (2018) No.04, p.2-9. (In Chinese). 